\title{
Restoration of Threatened Arable Weed Communities in Abandoned Mountainous Crop Fields
}

\author{
Florian Kohler, ${ }^{1,2}$ Charlotte Vandenberghe, ${ }^{3}$ Ralph Imstepf, ${ }^{2}$ and François Gillet ${ }^{1,2,4,5}$
}

\begin{abstract}
Arable fields maintaining species-rich weed communities have almost disappeared from European mountain areas due to their abandonment or replacement by extensive grazing systems during the last decades. The restoration of arable weed communities have become an important issue in these habitats which have a large potential to contain rare and threatened (red-list) species. In a site in the Swiss Alps, formerly managed for crop production, we investigated in experimental plowed plots the 1-year effects of fertilizing, sowing a mixture of arable weed species and sowing a crop species (triticale) on the natural regeneration (species richness and cover) of arable weed and non-weed species. The high number of newly appeared arable weed species, of which four were red-list species, indicated that propagule availability was still important after about 50 years of arable field abandonment. Plowed
\end{abstract}

plots which did not receive any treatment and those with fertilization alone favored the regeneration of both wild weed and non-weed species. The crop species limited, but did not inhibit, the recovery success of weed and nonweed species and this negative effect tended to be higher under fertilization. Sowing of arable weed seeds decreased the natural regeneration of both weeds and non-weeds in the absence of triticale. Our results show that plowing is a promising method to successfully restore the weed community in abandoned arable mountain areas. Moreover, the sowing of weed species in combination with a crop species might produce sustainable food and restore and maintain the diversity of threatened arable weeds at the same time.

Key words: abandoned crop field, agro-biodiversity, fertilizer, natural regeneration, seed sowing, triticale production.

\section{Introduction}

Although arable weeds are a major constraint on crop production, they have an important role within agro-ecosystems in supporting biodiversity (Marshall et al. 2003). Arable weeds are generally ruderal annuals which grow in close association with crops. They include a high diversity of plant species of which the success to persist in highly disturbed, arable systems depends on a number of specific life-history characteristics including high seed production, long seed persistence in the soil seed bank and rapid development rates (Cousens \& Mortimer 1995; Rao 2000). Moreover, species-rich weed communities support directly or indirectly through the food web, a high diversity of insect and bird species (Marshall et al. 2003; Hyvönen \& Huusela-Veistola 2008), and can therefore impact ecosystem functions and services such as pollination or pest control (Tscharntke et al. 2005).

\footnotetext{
${ }^{1}$ Ecole Polytechnique Fédérale de Lausanne EPFL, Ecological Systems Laboratory ECOS, Station 2, 1015 Lausanne, Switzerland

${ }^{2}$ University of Neuchâtel, Soil and Vegetation Laboratory, Rue Emile-Argand 11, 2007 Neuchâtel, Switzerland

${ }^{3}$ Swiss Federal Research Institute WSL, Station 2, 1015 Lausanne, Switzerland

4 Address correspondence to F. Gillet, email francois.gillet@univ-fcomte.fr

${ }^{5}$ Present address: Université de Franche-Comté/CNRS, UMR 6249

Chrono-environnement, 16 Route de Gray, 25030 Besançon Cedex, France

(C) 2010 Society for Ecological Restoration International

doi: 10.1111/j.1526-100X.2009.00641.x
}

In Europe, there has been an overall severe decline in arable weed communities since the middle of the last century with an increase in the number of arable weed species in European Red Data Lists as a consequence (Moser et al. 2002). A wide range of arable weed species should therefore no longer be treated as species that need to be controlled and eliminated in order to enhance crop production but need specific conservation and restoration management in order to avoid their extinction (Sutcliffe \& Kay 2000; Türe \& Böcük 2008; Fried et al. 2009). The dramatic loss of arable weeds in lowlands results from an increasing agricultural intensification (Sutcliffe \& Kay 2000; Stoate et al. 2001; Baessler \& Klotz 2006; Hyvönen \& Huusela-Veistola 2008; Fried et al. 2009) whereas in mountainous regions it is related to decreasing agricultural practices (MacDonald et al. 2000). In the Alps, traditional labor-demanding practices related to arable field management have often been replaced by extensive grazing systems or abandoned to natural reforestation and a homogenization of the landscape as a consequence (Laiolo et al. 2004; Scozzafava \& De Sanctis 2006). Thus although arable fields are among the most widespread and intensive management in the lowland of Western Europe (e.g. 38\% of the total area in Germany (Albrecht 2003)), they have almost disappeared from the mountainous areas (Begueria 2006). 
In the current context of agricultural intensification, initiatives to restore arable weed habitats and conserve rare weeds have mainly focussed on extensification of agricultural practices (e.g. reduction in fertilizer and herbicide) and the establishment of arable field margins stimulated by agrienvironmental schemes and payments (e.g. Kleijn \& van der Voort 1997; Smith et al. 1999; Sutcliffe \& Kay 2000; Marshall \& Moonen 2002; Albrecht 2005). Agricultural extensification will favor arable weeds because they are in general negatively influenced by fertilizers and the introduction of crop species at high densities, due to high competitive pressure for light and nutrients (Bischoff \& Mahn, 2000; Walker et al. 2007; Fried et al. 2009). Moreover, the success of recovery of specific plant species in transformed habitats depends largely on propagule availability (Bischoff 2005; Ruprecht 2006). Restoring arable weed habitats will therefore largely depend on soil seed bank density and/or on the propagule immigration from surrounding areas. However, when soil seed banks are lost due to long-term intensive cultivation (Bischoff \& Mahn 2000) or when connections to external neighboring propagule sources are scarce (Gabriel et al. 2005), seed sowing might be needed to ensure successful restoration of the arable weed community (Eggenschwiler et al. 2004; Bischoff 2005). Many studies have focused on the recolonization of weeds from field margin strips in the adjacent intensively managed crop (e.g. Smith et al. 1999; Marshall \& Moonen 2002; Walker et al. 2007; De Cauwer et al. 2008; Fried et al. 2009). In contrast, we found only one study that investigated the ecological restoration of arable weed communities through plowing of meadows formerly managed as crop fields (Dutoit et al. 2003). This approach should, however, be further explored as it might be essential for the restoration and long-term conservation of the threatened arable weed communities in the abandoned arable fields currently present in many mountain areas.

The aim of this study was to test, experimentally, different post-plowing treatments to restore the arable weed community in a site in the Swiss Alps managed for crop production till the early sixties and converted afterwards to extensively managed sheep pastures. The site typically exists out of old, species-rich terraces which have a large potential to contain rare and threatened (weed) species due to the particular climatic conditions and low-intensity agricultural management (Waldis 1987). We measured in experimental plowed areas the separate and combined effects of fertilizing, sowing a mixture of arable weed species and sowing a crop species (triticale: $\times$ Triticosecale Whitm.) on the natural regeneration of arable weed and non-weed species. We measured the seed production of two sown arable weed species and of the crop. We specifically wanted to investigate (1) how many, and which, arable wild weed species regenerate after plowing, (2) which treatment favors the natural regeneration of arable weeds and non-weeds, and (3) how treatments influence arable weed and triticale seed production. We hypothesized that (1) sowing arable weeds and triticale will have a negative impact on the natural regeneration of the arable weeds and non-weeds, and that this negative impact will be increased by fertilization, (2) fertilization will increase the cover and seed production of the arable weeds but not species richness, (3) sown arable weeds and the absence of fertilization will have a negative impact on seed production of triticale.

\section{Methods}

\section{Study Site}

The experiment was conducted at Unneri Zälg near Jeizinen $\left(46^{\circ} 19^{\prime} 24^{\prime \prime} \mathrm{N}, 7^{\circ} 43^{\prime} 46^{\prime \prime} \mathrm{E}, 1230 \mathrm{~m}\right.$ a.s.l.) on the south-facing slope of the main Rhone valley (Wallis, Switzerland). This inner-alpine valley is characterized by a dry climate with a yearly mean precipitation of approximately $600 \mathrm{~mm}$, of which most falls as snow during winter. Mean daytime air temperature and total precipitation during the growing season (1 April to 30 September) of 2004 was about $16^{\circ} \mathrm{C}$ and $185 \mathrm{~mm}$, respectively (Zweifel et al. 2006). The site consists of old terraces that were traditionally cultivated for triticale production till the early sixties and converted afterwards to extensively managed sheep pastures (Waldis 1987; farmer interviews; Fig. 1). The soil (pH of 6-7) is an Anthrosol (IUSS 2006) generated by human activities during terrace creation. The texture is sandy and the first $25 \mathrm{~cm}$ of the soil contains a large proportion of stones with a diameter larger than $10 \mathrm{~cm}$. The maximum depth of the roots of the meadow is rarely deeper than $20 \mathrm{~cm}$.

\section{Experimental Design}

A blocked factorial field experiment involving four blocks and three 2-level factors was set up during autumn 2003 (Fig. 2).

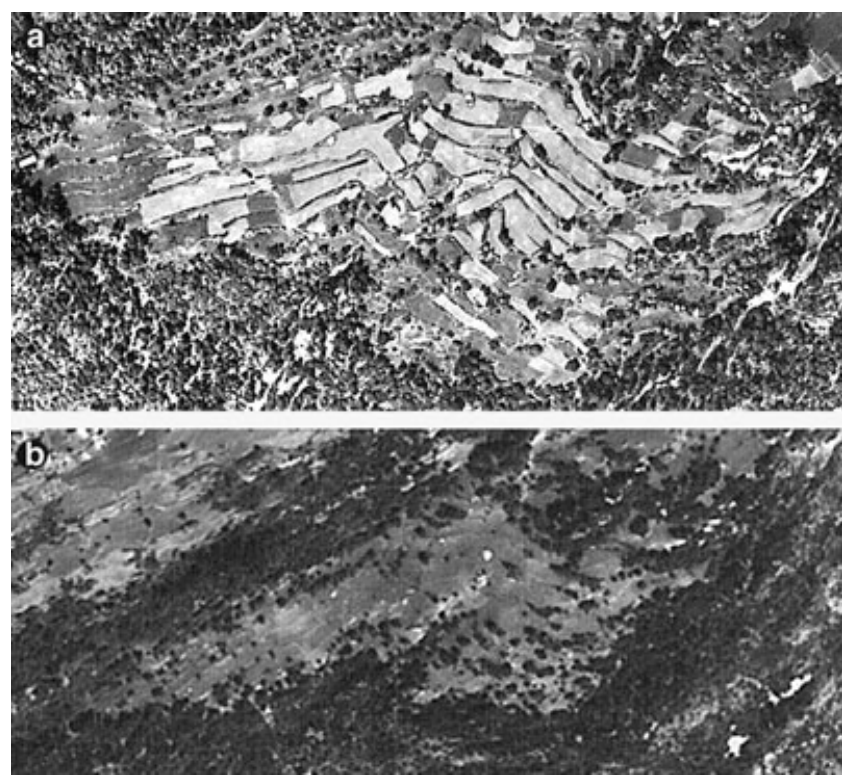

Figure 1. Aerial photographs of Unneri Zälg between Jeizinen and Gampel (Wallis, Switzerland) in (a) 1941 and (b) 1999, before and after the conversion of old terraces that were traditionally cultivated for triticale production to extensively managed sheep pastures (courtesy of Swisstopo). 
$10.7 \mathrm{~m}$
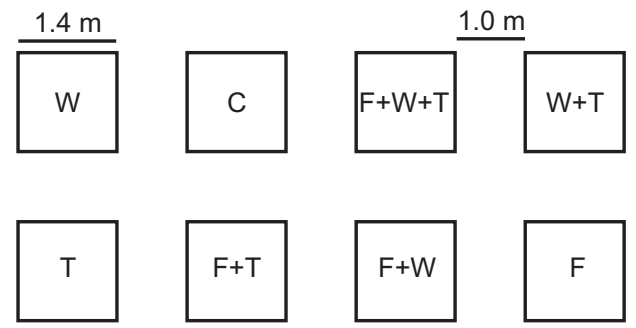

Block 1
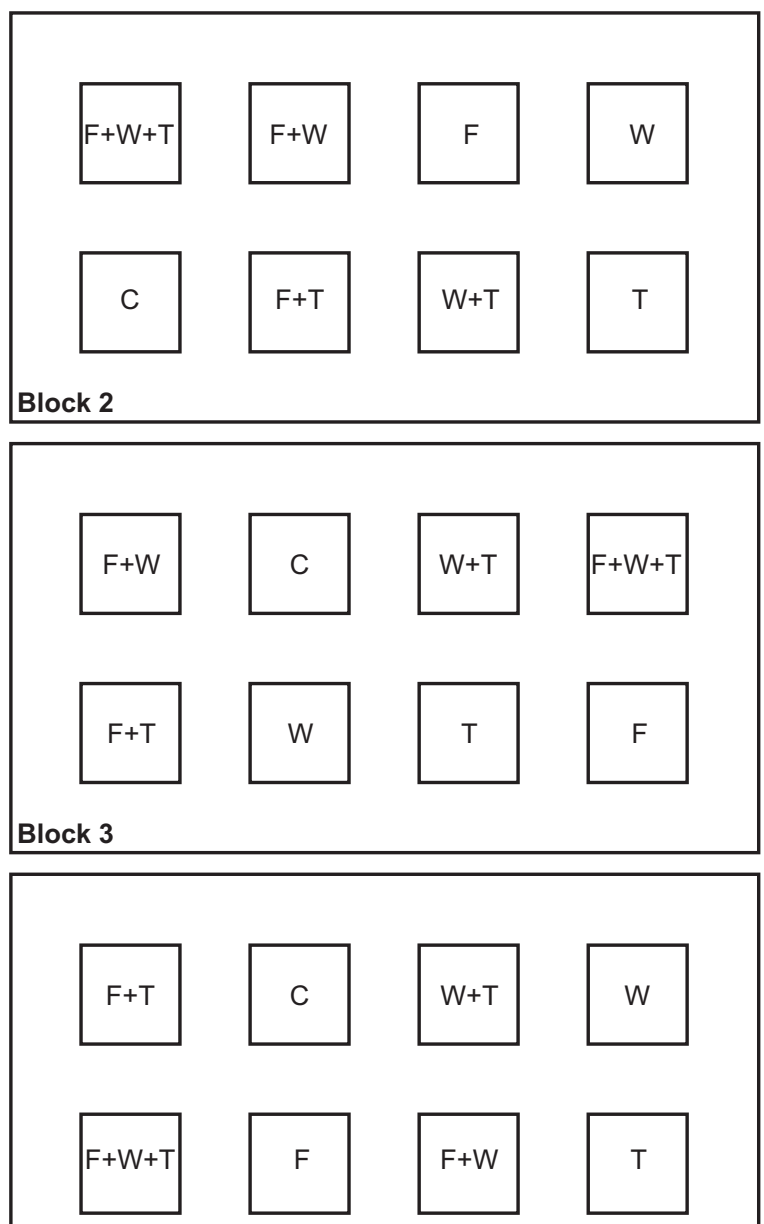

Block 4

Figure 2. Experimental design: four blocks containing each eight plots of $2 \mathrm{~m}^{2}$. F, fertilizing; W, sowing arable weed species; T, sowing of triticale; $\mathrm{C}$, control (i.e. only plowed).

The three 2-level factors were: (1) fertilizing (F), (2) sowing of arable weed species (W), and (3) sowing of triticale (T). In the study site, four blocks of $11 \times 6 \mathrm{~m}$ were fenced to exclude sheep and plowed at a depth of $25 \mathrm{~cm}$, which corresponded to the traditional practice. The blocks were between 10 and $50 \mathrm{~m}$ apart. Eight plots of $2 \mathrm{~m}^{2}$ were laid out in each block over two rows and $1 \mathrm{~m}$ spaced from each other.
Plots that were submitted to fertilization $\left(\mathrm{F}_{1}\right)$ received about $2.5 \mathrm{~kg} / \mathrm{m}^{2}$ of sheep manure. This quantity corresponded to the standard amount of fertilizer used for triticale cultivation (Ryser et al. 2001). Wooden planks were vertically placed in the soil around each fertilized plot to avoid fertilization of the unfertilized plots.

The second factor involved sowing of arable weed species. Half of the plots received seeds of 12 arable weed species $\left(\mathrm{W}_{1}\right)$ (see Table 1 for details on species, seed quantities and origin, nomenclature follows Tutin et al. [1964-1980]). To avoid confusion between sown species and naturally regenerated species, only weed species presently absent from the vegetation in the experimental blocks (see Section Vegetation Surveys) but indigenous in central Wallis were selected. However, it could not be excluded that the selected species were still present in the soil seed bank.

The third factor involved sowing of triticale. Approximately $425 \mathrm{seeds} / \mathrm{m}^{2}$ of triticale, cultivar Prader, were sown in half of the plots $\left(\mathrm{T}_{1}\right)$. This crop is a hybrid of Triticum durum/aestivum (wheat) and Secale cereale (rye), which is known to resist harsh mountain climates. In each block, eight treatments (all combinations of the three factors: $\mathrm{F}_{1}\left(+\mathrm{W}_{0}+\mathrm{T}_{0}\right), \quad \mathrm{W}_{1}\left(+\mathrm{F}_{0}+\mathrm{T}_{0}\right), \quad \mathrm{T}_{1}\left(+\mathrm{F}_{0}+\mathrm{W}_{0}\right), \quad \mathrm{F}_{1}+\mathrm{W}_{1}$ $\left(+\mathrm{T}_{0}\right), \mathrm{F}_{1}+\mathrm{T}_{1}\left(+\mathrm{W}_{0}\right), \mathrm{W}_{1}+\mathrm{T}_{1}\left(+\mathrm{F}_{0}\right), \mathrm{F}_{1}+\mathrm{W}_{1}+\mathrm{T}_{1}$ and control $\left.\left(\mathrm{F}_{0}+\mathrm{W}_{0}+\mathrm{T}_{0}\right)\right)$ were randomly assigned to each of the eight plots (Fig. 2).

\section{Vegetation Surveys}

An exhaustive list of the arable weed species still present in the area formerly cultivated for triticale production was made in a 20-ha radius around the experimental site during spring and summer 2002 and 2003. Intensive surveys were carried out in suitable habitats for these remnant weed species, such as old terraces, trampled areas, rock outcrops, and roadside verges.

In summer 2003, before plowing, an exhaustive list of all plant species and their absolute cover was recorded in each

Table 1. List of the 12 sown arable weed species (seed provenance: the Brentjong region in central Wallis, Switzerland) (W treatment) with their red-list status (following the Swiss red list of Moser et al. [2002]) and the number of sown seeds per $\mathrm{m}^{2}$.

\begin{tabular}{lccc} 
& & \multicolumn{2}{c}{ Amount of Sown Seeds } \\
\cline { 3 - 4 } Species & Red-List Status & Weight $(g)$ & Number \\
\hline Adonis aestivalis & VU & 3.0 & 180 \\
Adonis flammea & EN & 0.5 & 150 \\
Agrostemma githago & VU & 3.0 & 370 \\
Androsace maxima & CR & 0.3 & 210 \\
Bupleurum rotundifolium & EN & 2.0 & 385 \\
Consolida regalis & VU & 1.5 & 855 \\
Nigella arvensis & EN & 1.5 & 1980 \\
Papaver argemone & VU & 0.1 & 750 \\
Ranunculus arvensis & VU & 0.2 & 20 \\
Scandix pecten-veneris & EN & 0.5 & 30 \\
Torillis arvensis & VU & 0.4 & 170 \\
Xeranthemum inapertum & CR & 2.5 & 650 \\
\hline
\end{tabular}

VU, vulnerable; EN, endangered; CR, critically endangered. 
of the four experimental blocks. During the experiment, we recorded monthly, from April to August 2004 (i.e. five times), in each $2 \mathrm{~m}^{2}$ plot, the presence of plant species and their absolute cover including triticale and the sown weed species. The absolute cover of each species at each observation was measured on the Londo's dominance scale (Dierschke 1994) with 13 classes $(1,2,5,10,20, \ldots, 90,100 \%)$. The absolute cover of each species within a plot was then averaged over the five surveys to derive a mean absolute plant cover per plot. The number of newly appeared arable weed species was deduced by comparing the list of species observed during the experiment with the species lists made before the experiment at the experimental site and in the neighboring area.

The observed plant species were classified in two groups following their habitat in central Wallis: (1) arable weed species (including both wild (i.e. naturally regenerated) and sown weed species), (2) non-weed species. The arable weed species were defined by Waldis (1987), Delarze et al. (1998), and Oberdorfer (2001) as species which develop only, or at least preferentially, in arable field habitats. The non-weed species were typical of dry meadows, rock outcrops, forest edges, or fallows not only strictly linked to arable field habitats but also able to colonize it. Moreover, the Swiss red-list status of each observed species was noted by Moser et al. (2002) (see Appendix S1, Supporting Information: species which are labeled VU, EN, or CR are considered to be red-list species).

In September 2004, the triticale was harvested in the central square meter of each plot with $\mathrm{T}_{1}$ and the fresh weight of the seeds was measured. Seeds of the two sown arable weed species Agrostemma githago (corncockle) and Ranunculus arvensis (corn buttercup) were collected in all plots with $\mathrm{W}_{1}$ and the fresh weight of the seeds was measured.

\section{Statistical Analysis}

The effects of fertilizing (F), sowing arable weed species (W), and sowing triticale (T) and their interactions on species richness and absolute plant cover, with blocks as replicated units, were tested with three-way ANOVAs. Posterior pairwise comparisons were made with Tukey HSD post hoc tests. Mean absolute plant cover (\%) was arcsine-transformed to improve the homogeneity of error variances. In order to differentiate the treatment effects on arable weed and nonweed species, analyses were done separately on (1) wild weed species, (2) wild plus sown weed species, and (3) non-weed species.

To test the hypotheses on seed production, two other complementary analyses were done. First, for plots including $\mathrm{W}_{1}$, the effects of fertilizing $(\mathrm{F})$ and sowing triticale $(\mathrm{T})$ and their interaction on the total seed weight of two sown weed species, A. githago and $R$. arvensis, were tested with a twoway ANOVA accounting for the block effect. Second, for plots including $\mathrm{T}_{1}$, the effects of fertilizing $(\mathrm{F})$ and sowing weed species (W) and their interaction on the total seed weight of triticale were also tested with a two-way ANOVA.

All statistical analyses were performed using $\mathrm{R}$ 2.8.1 (R Development Core Team 2008).

\section{Results}

\section{Regeneration of Arable Weed Species}

Twenty-seven species of arable weeds were observed in the area around the experimental site. Three of these species were among the selected sown species. Most of these species were low in frequency and restricted to small disturbed areas such as trampled paths or eroded steep slopes. Before plowing, 107 plant species were found over the 4 blocks and 17 of them were arable weeds (mean number $[ \pm \mathrm{SE}]$ per block $=9[ \pm 1.1]$ ). During the experiment, a total of 95 plant species were observed (sown weed species and triticale excluded) of which 27 were arable weeds (mean number $[ \pm \mathrm{SE}]$ per plot $=8.5$ [ \pm 0.4$]$ ) (see Appendix S1, Supporting Information for the complete list of species). The sown weed species were only observed within the treated plots. Eleven of the 27 arable weed species were not observed in the blocks before plowing (16 weeds were still present and one disappeared) and 8 of them did not even occur in the area around the experimental site (see Appendix S1, Supporting Information for identification of these species). Of the 11 new arable species, an average $( \pm \mathrm{SE})$ of $1.47( \pm 0.22)$ species per plot appeared and there were no treatment effects. Four of the 11 newly appeared weed species were classified as red-list species for Switzerland (i.e. Polycnemum arvense L. (field needleleaf), Polycnemum majus A. Braun (giant needleleaf), Odontites vulgaris Moench (red bartsia), Veronica triphyllos L. (finger speedwell)). In total, 6 red-list arable weed species (mean number $[ \pm \mathrm{SE}]$ per plot $=$ $0.56[ \pm 0.14])$ were recorded and there were no treatment effects. Moreover, Lathyrus setifolius L. (narrow-leaved red vetchling), which was never recorded in Switzerland before, was observed in between the experimental plots.

\section{Fertilizer, Weed and Triticale Sowing Effects on Species Richness and Plant Cover}

Multiple significant interactions between the main treatments occurred, especially for absolute plant cover responses (Table 2). The species richness and cover of arable weeds (natural and sown together) were obviously highest in the plots which received the mixture of the 12 sown weed species (Fig. 3a \& 3c). Significant differences between blocks were observed (Table 1).

Triticale significantly decreased species richness of nonweed species but only in plots where no arable weeds were sown (interaction $\mathrm{W} \times \mathrm{T}$; Table 2). Triticale also decreased species richness of wild and sown arable weeds but especially in combination with fertilization (marginally significant interaction $\mathrm{F} \times \mathrm{T}$; Table 2). Fertilization did not significantly influence species richness although it tended to increase the number of non-weed species in absence of sown weeds (marginally significant interaction $\mathrm{F} \times \mathrm{W}$; Fig. 3b). Sown arable weeds had a significant negative effect on the species number of wild weeds (Table 2).

The cover of wild weeds and non-weeds was negatively influenced by sown weeds in the absence of triticale (interaction $\mathrm{W} \times \mathrm{T}$; Table 2). In other words the negative effect of 
Table 2. Results of the three-way ANOVA table with the fixed effects of fertilizer (F), sowing arable weed species (W), and sowing of triticale (T) on species richness and plant cover.

\begin{tabular}{|c|c|c|c|c|c|c|c|}
\hline & \multicolumn{3}{|c|}{ Species Richness } & \multicolumn{4}{|c|}{ Absolute Cover } \\
\hline Block & 3 & $3.3^{* *}$ & $3.2^{* *}$ & $3.1^{* *}$ & $5.8^{* * *}$ & $14.3^{* * * *}$ & 1.7 \\
\hline W & 1 & $4.7^{* *}$ & $292.8^{* * * *}$ & $17.1^{* * * *}$ & $25.2^{* * * * *}$ & $786.2^{* * * *}$ & $90.5^{* * * *}$ \\
\hline $\mathrm{T}$ & 1 & $15.9^{* * * *}$ & $14.1^{* * *}$ & $11.9^{* * *}$ & $36.3^{* * * *}$ & $315.5^{* * * *}$ & $79.3^{* * * *}$ \\
\hline $\mathrm{F} \times \mathrm{W}$ & 1 & 1.0 & 0.3 & $3.0^{*}$ & 0.0 & $47.0^{* * * *}$ & $7.4^{* *}$ \\
\hline $\mathrm{F} \times \mathrm{W} \times \mathrm{T}$ & 1 & 0.3 & 0.6 & 0.8 & 2.6 & $27.3^{\text {***** }}$ & 3.0 \\
\hline Residuals (MS) & 21 & 2.412 & 2.700 & 9.470 & 0.0011 & 0.0011 & 0.0022 \\
\hline
\end{tabular}

$F$ values are presented for the factors and mean squares (MS) for the residuals. Analyses were done separately on wild weed species (weeds I), wild plus sown weed species (weeds II), and non-weed species (others).

$* * * *<<0.001 ; * * * p<0.01 ; * * p<0.05 ; * p<0.1$.
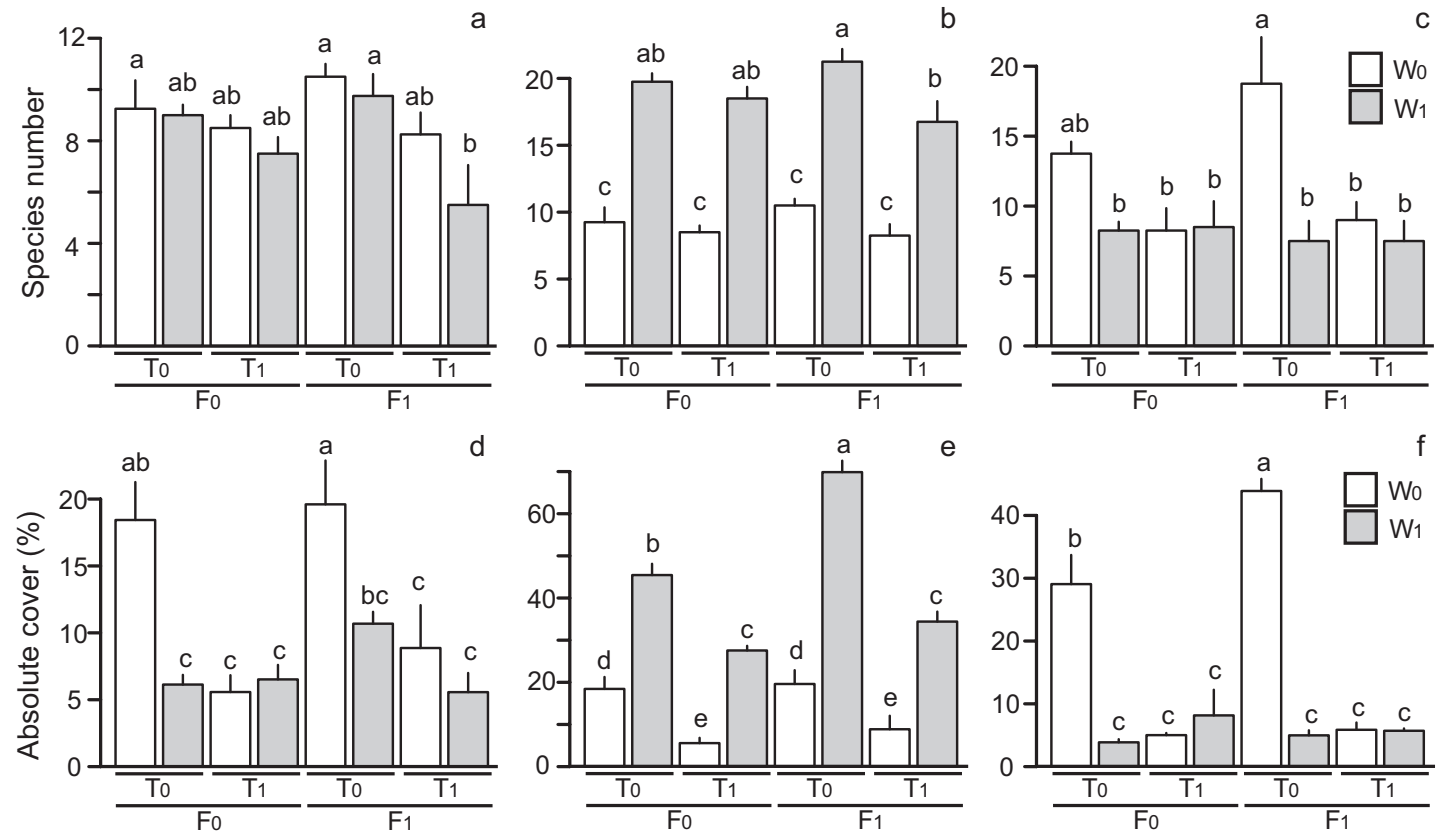

Figure 3. Effects of fertilization $\left(\mathrm{F}_{0}\right.$ : no fertilizer, $\mathrm{F}_{1}$ : fertilizer added), sowing arable weed species ( $\mathrm{W}_{0}$ : no sown weeds, $\mathrm{W}_{1}$ : weed seeds added), and sowing of triticale ( $\mathrm{T}_{0}$ : no triticale, $\mathrm{T}_{1}$ : triticale seeds added) on the species number of (a) wild weed species, (b) wild and sown weed species and (c) non-weed species, and on the absolute cover of (d) wild weed species, (e) wild and sown weed species, and (f) non-weed species. Means per treatment and standard errors are presented. See Table 2 for results of the corresponding three-way ANOVAs. Different letters indicate significant different means resulting from the Tukey HSD post hoc comparisons $(p<0.05)$.

triticale on cover of wild weeds and non-weed species occurred only in $\mathrm{W}_{0}$ plots (Fig. 3). As for species richness, fertilization did not have a significant effect on cover of wild weed species. Fertilization did, however, increase the cover of sown weeds and non-weeds but only in plots without triticale (interaction $\mathrm{F} \times \mathrm{T}$; Table 2).

\section{Seed Production}

A significant interaction between fertilization and triticale was found for seed production of two sown arable weeds (Fig. 4): the significant positive effect of fertilizer on seed production was decreased by triticale for A. githago and only present in the absence of triticale for $R$. arvensis. The seed production of triticale was negatively affected by the presence of the sown species but positively increased by fertilizing (Fig. 5). Interestingly, triticale decreased seed production of sown weeds only at the high level of fertilizing (Fig. 4), whereas sown weeds decreased seed production of triticale mostly at the low level of fertilizing (Fig. 5).

\section{Discussion}

This study shows the high potential of arable weed community restoration after plowing in abandoned arable fields because the species richness and cover of natural regenerated weeds were relatively high. The reappearance of 11 arable weeds, of which 4 are red-list species, indicates that propagule 


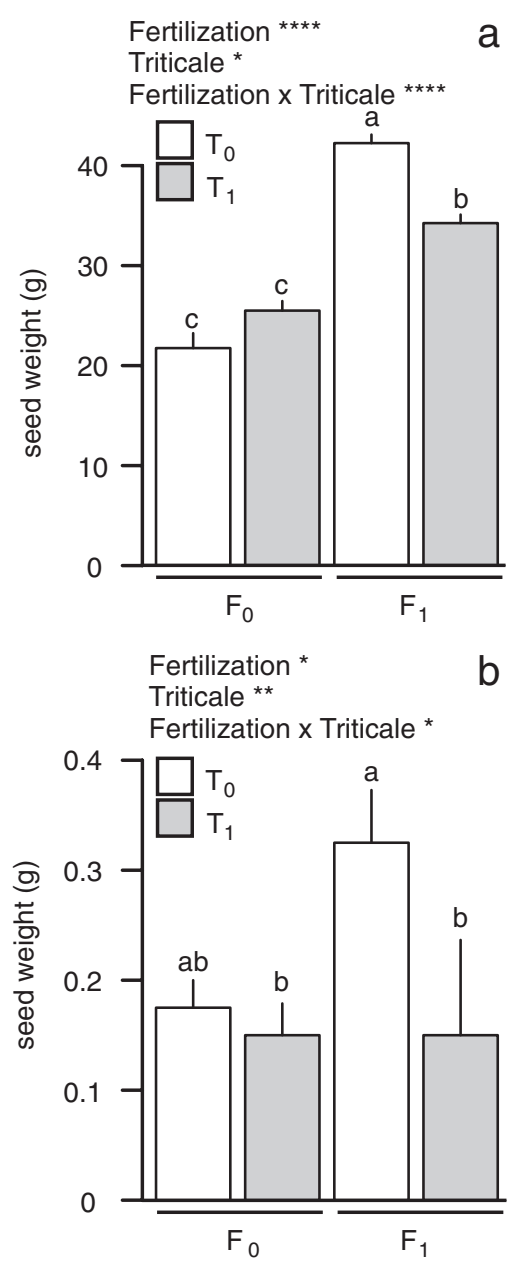

Figure 4. Effect of fertilization $\left(\mathrm{F}_{0}\right.$ : no fertilizer, $\mathrm{F}_{1}$ : fertilizer added $)$ and sowing of triticale $\left(\mathrm{T}_{0}\right.$ : no triticale, $\mathrm{T}_{1}$ : triticale seeds added) on seed production of the sown arable weed species (present in $\mathrm{W}_{1}$ plots): (a) Agrostemma githago; (b) Ranunculus arvensis. Means and standard errors are shown. The results of the two-way ANOVAs are presented in the top-left corner $(* * * * p<0.001 ; * * p<0.05 ; * p<0.1)$.

availability is still important after about 50 years of arable field abandonment. Dutoit et al. (2003) showed that only 2 out of 10 germinated arable weed species persisted in the seed bank of a 10-year-old extensively pastured meadow. They related the appearance of the other eight weed species after plowing to dispersal via herbivore exozoochory. We were not able to investigate if species originated from dispersal or from the permanent seed bank, but both sources most likely played a significant role. It is likely that the remnant populations within and around the study site served as a seed source for some species. Dispersal distances of weeds are generally limited to a few meters (Bischoff 2005; De Cauwer et al. 2008) but sporadic long distance dispersal events can occur through zoochory (Fischer et al. 1996) or transport by mowing and cultivating machinery (Strykstra et al. 1996). However, it is highly probable that the eight newly appearing weed species in the experimental site originated from the soil seed bank as they were not observed in the neighboring 20-ha area. The seeds of these eight annual

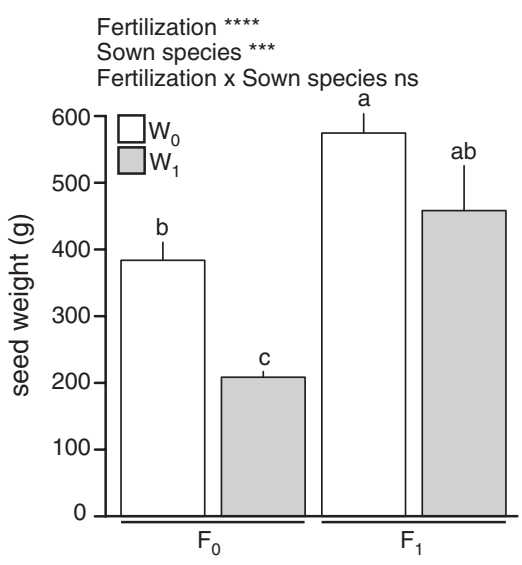

Figure 5. Effect of fertilization $\left(\mathrm{F}_{0}\right.$ : no fertilizer, $\mathrm{F}_{1}$ : fertilizer added $)$ and sowing arable weed species $\left(\mathrm{W}_{0}\right.$ : no sown weeds, $\mathrm{W}_{1}$ : weed seeds added) on seed production of triticale (present in $\mathrm{T}_{1}$ plots). Means and standard errors are shown. The results of the two-way ANOVAs are presented in the top-left corner $(* * * * p<0.001 ; * * * p<0.01$; $n s$ : not significant).

weed species likely survived for more than 50 years because it is a common strategy of arable weeds to form long-term persistent seed banks in a predictable environment (Thompson et al. 1997; Sutcliffe \& Kay 2000; Lososová et al. 2006). The moderate plowing, as it was traditionally practiced, is likely to have enhanced germination and survival conditions for most of the regenerated species and did not bury seeds too deeply to impede successful germination (Luzuriaga et al. 2005). Moreover, the reintroduction of this practice several decades after the cultivation was likely to bring old seeds close to the surface so that they could germinate in the bare soil.

The sown arable weed seeds showed a successful establishment which was highest in plots combining the presence of fertilizer and the absence of the crop species. The use of seed mixtures in restoration and habitat creation was also successfully used in the case of wild flower strips in intensively managed arable land with the occurrence of a large number of sown species in the seed bank one year following establishment (Eggenschwiler et al. 2004). So, the introduction of species during the first year might be sufficient to restore arable weed communities. Many authors point out the importance of using, if possible, local seed provenances due to their enhanced adaptation to local conditions (e.g. Bischoff et al. 2006) and the reduction of environmental risks such as outbreeding depression (e.g. Keller et al. 2000).

Although the sown seeds made a significant contribution to the restoration of the weed community, they decreased the natural regeneration of both arable weeds and non-weeds in absence of triticale. In fact, the plots which favored the species richness and cover of both wild weed and non-weed species were those who did not receive any treatment after plowing $\left(\mathrm{F}_{0} \mathrm{~W}_{0} \mathrm{~T}_{0}\right)$ and those with fertilization alone $\left(\mathrm{F}_{1} \mathrm{~W}_{0} \mathrm{~T}_{0}\right)$. So as predicted by our first hypothesis, the sown arable weeds and the crop species were able to limit the recovery success of weed (and non-weed) species and the negative effect of triticale tended to be higher in fertilized plots. Moreover, 
the positive effect of fertilizer on the seed production of the two selected sown weed species was significantly reduced by triticale. These results confirm the observations that fertilizer has in general a negative effect on weed diversity and abundance in cultivated fields due to increased competition for resources with the crop species (Pysek \& Leps 1991; Wilson \& Tilman 1993; Kleijn \& van der Voort 1997; Bischoff \& Mahn 2000). However, there was an overall positive effect of fertilization on weed cover and seed production, as predicted by hypothesis 2 . This can be explained by the ruderal strategy of these species, which require high nutrient availability but are poor competitors (sensu Grime 1979). The fact that there were no significant differences in the number or cover of wild weeds (and non-weeds) between unfertilized and fertilized triticale plots, and that sown weed species negatively influenced triticale seed production (hypothesis 3), mostly at low fertility level, confirms the potential of weeds to compete with the crop species and persist - to a certain extent — within the crop field (Cousens \& Mortimer 1995; Dutoit et al. 2001). So, although triticale will successfully compete with many weed species because of its large leaves and tallness (Guedes-Pinto et al. 1996), weeds might also have a competitive advantage over the crop species, especially in absence of fertilization. The outcome of the symmetric competition between triticale and weeds depends on the fertilizer level, as shown by our experiment. The competitiveness of weeds will depend, among other factors, on the species and density of the weeds, the amount and type of fertilizer, growth and development abilities of the crop species, and climate conditions (Rao 2000).

For decades, farmers have been trying to minimize weed growth in the crop field to an acceptable level by using manual, mechanical, chemical, and biological approaches. However, the position of arable weeds as a valuable part of plant diversity and an important gene source in arable ecosystems can no longer be ignored (Türe \& Böcük 2008). Thus, as for intensive cultivations in the European lowland, restoration, and maintenance of arable weed habitats in mountain areas should be promoted through agri-environment schemes. The increase of endangered species diversity requires more elaborate conservation measures than the conservation of common species (Kleijn et al. 2006, but see Fried et al. 2009). Therefore, specific agri-environmental schemes, with particular attention on red-list species, should be defined for mountainous habitats that can harbor many rare or threatened plant species over short distances.

\section{Implications for Practice}

- Arable weed species in mountainous areas should no longer be treated as species that need to be eliminated in order to enhance crop production but as species that need specific conservation or restoration management in order to avoid their extinction.

- Management efforts should, firstly, concentrate on the plowing of abandoned mountainous crop fields, and secondly, on the reintroduction of arable weed species by sowing to restore common and rare weed species. Although the sowing of arable weed seeds decreased the natural regeneration of both weeds and non-weeds, it will increase the restoration success of the arable weed community, especially in the case of limited propagule availability from the soil seed bank or from surrounding seed sources. To ensure the survival of these species in the long term, plowing should be repeated every year, so that a portion of the landscape is actively restored.

- The sowing of a crop species after plowing within the abandoned fields will, even with the addition of organic fertilizer, decrease but not inhibit the recovery of wild weed and non-weed species.

- The restoration of abandoned, traditional arable fields in the Alps could be advantageous for both food production and biological diversity. The traditional agriculture practices (plowing and seed additions) will produce sustainable and diverse food with high potential income and increase and maintain the diversity of threatened arable weeds at the same time.

\section{Acknowledgments}

We thank the farmers for the use of their fields near Jeizinen and R. Waldis, J.-M. Gobat, and J.-D. Gallandat for their useful comments on the experimental design and vegetation surveys. We are grateful to the two anonymous reviewers and the Coordinating Editor for their help in improving the manuscript.

\section{LITERATURE CITED}

Albrecht, H. 2003. Suitability of arable weeds as indicator organisms to evaluate species conservation effects of management in agricultural ecosystems. Agriculture Ecosystems \& Environment 98:201-211.

Albrecht, H. 2005. Development of arable weed seedbanks during the 6 years after the change from conventional to organic farming. Weed Research 45:339-350.

Baessler, C., and S. Klotz. 2006. Effects of changes in agricultural land-use on landscape structure and arable weed vegetation over the last 50 years. Agriculture, Ecosystems and Environment 115:43-50.

Begueria, S. 2006. Changes in land cover and shallow landslide activity: a case study in the Spanish Pyrenees. Geomorphology 74:196-206.

Bischoff, A. 2005. Analysis of weed dispersal to predict chances of recolonisation. Agriculture Ecosystems \& Environment 106:377-387.

Bischoff, A., and E. G. Mahn. 2000. The effects of nitrogen and diaspore availability on the regeneration of weed communities following extensification. Agriculture Ecosystems \& Environment 77:237-246.

Bischoff, A., B. Vonlanthen, T. Steinger, and H. Müller-Schärer. 2006. Seed provenance matters - effects on germination of four plant species used for ecological restoration. Basic and Applied Ecology 94: 1130-1142.

Cousens, R., and M. Mortimer. 1995. Dynamics of weed populations. Cambridge University Press, Cambridge.

De Cauwer, B., D. Reheul, I. Nijs, and A. Milbau. 2008. Management of newly established field margins on nutrient-rich soil to reduce weed spread and seed rain into adjacent crops. Weed Research 48:102-112.

Delarze, H., Y. Gonseth, and P. Galland. 1998. Guide des milieux naturels de Suisse-écologie, menaces, espèces caracteristiques. Delachaux et Niestlé, Lausanne, Paris, 413 pp. 
Dierschke, H. 1994. Pflanzensoziologie. Grundlagen und Methoden. Ulmer, Stuttgart, $683 \mathrm{pp}$.

Dutoit, T., E. Gerbaud, E. Buisson, and P. Roche. 2003. Dynamics of a weed community in a cereal field created after ploughing a seminatural meadow: roles of the permanent seed bank. Ecoscience 10: 225-235.

Dutoit, T., E. Gerbaud, J.-M. Ourcival, M. Roux, and D. Alard. 2001. A prospective research on the duality between morphological traits and plant competitive abilities: the case of weed species and wheat. Comptes rendus de l'Académie des sciences Paris, Life Sciences 324: 261-272.

Eggenschwiler, L., K. Jacot, S. Studer, and P. Edwards. 2004. Influence of seed mixtures on the development of the seed bank of wildflower strips and rotational fallows and the persistence of species in the subsequent crop. Botanica Helvetica 114:49-66.

Fischer, S. F., P. Poschlod, and B. Beinlich. 1996. Experimental studies on the dispersal of plants and animals on sheep in calcareous grasslands. Journal of Applied Ecology 33:1206-1222.

Fried, G., S. Petit, F. Dessaint, and X. Reboud. 2009. Arable weed decline in Northern France: crop edges as refugia for weed conservation? Biological Conservation 142:238-243.

Gabriel, D., C. Thies, and T. Tscharntke. 2005. Local diversity of arable weeds increases with landscape complexity. Perspectives in Plant Ecology, Evolution and Systematics 7:85-93.

Grime, J. P. 1979. Plant strategies and vegetation processes. Wiley, New York.

Guedes-Pinto, H., N. Darvey, and V. P. Carnide. 1996. Triticale: today and tomorrow (developments in plant breeding). Kluwer Academic Publishers, Dordrecht, Netherlands.

Hyvönen, T., and E. Huusela-Veistola. 2008. Arable weeds as indicators of agricultural intensity - a case study from Finland. Biological Conservation 141:2857-2864.

IUSS. 2006. World reference base for soil resources. 2nd edition. No 103. Food and Agricultural Organization of the United Nations (FAO), Rome, Italy.

Keller, M., J. Kollmann, and P. J. Edwards. 2000. Genetic introgression from distant provenances reduces fitness in local weed populations. Journal of Applied Ecology 37:647-659.

Kleijn, D., R. A. Baquero, Y. Clough, M. Diaz, J. De Esteban, F. Fernandez, et al. 2006. Mixed biodiversity benefits of agri-environment schemes in five European countries. Ecology Letters 9:243-254.

Kleijn, D., and L. A. C. vanderVoort. 1997. Conservation headlands for rare arable weeds: the effects of fertilizer application and light penetration on plant growth. Biological Conservation 81:57-67.

Laiolo, P., F. Dondero, E. Ciliento, and A. Rolando. 2004. Consequences of pastoral abandonment for the structure and diversity of the alpine avifauna. Journal of Applied Ecology 41:294-304.

Lososová, Z., M. Chytrý, I. Kühn, O. Hájek, V. Horáková, P. Pyšek, and L. Tichý. 2006. Patterns of plant traits in annual vegetation of man-made habitats in central Europe. Perspectives in Plant Ecology, Evolution and Systematics 8:69-81.

Luzuriaga, A. L., A. Escudero, J. M. Olano, and J. Loidi. 2005. Regenerative role of seed banks following an intense soil disturbance. Acta OecologicaInternational Journal of Ecology 27:57-66.

MacDonald, D., J. R. Crabtree, G. Wiesinger, T. Dax, N. Stamou, P. Fleury, J. G. Lazpita, and A. Gibon. 2000. Agricultural abandonment in mountain areas of Europe: environmental consequences and policy response. Journal of Environmental Management 59:47-69.

Marshall, E. J. P., V. K. Brown, N. D. Boatman, P. J. W. Lutman, G. R. Squire, and L. K. Ward. 2003. The role of weeds in supporting biological diversity within crop fields. Weed Research 43:77-89.

Marshall, E. J. P., and A. C. Moonen. 2002. Field margins in northern Europe: their functions and interactions with agriculture. Agriculture, Ecosystems \& Environment 89:5-21.

Moser, D. M., A. Gygax, B. Bäumler, N. Wyler, and R. Palese. 2002. Liste rouge des espèces menacées de Suisse: fougères et plantes à fleurs. Office fédéral de l'environnement des forêts et du paysage, Berne; Centre du Réseau Suisse de Floristique, Chambésy; Conservatoire et Jardin botanique de la ville de Genève, Chambésy.
Oberdorfer, E. 2001. Pflanzensoziologische Exkursionsflora für Deutschland und angrenzende Gebiete. Ulmer, Stuttgart, $1051 \mathrm{pp}$.

Pysek, P., and J. Leps. 1991. Response of a weed community to nitrogenfertilization - a multivariate-analysis. Journal of Vegetation Science 2:237-244.

Rao, V. S. 2000. Principles of weed science. Science Publishers, New Hampshire, USA.

R Development Core Team. 2008. R: a language and environment for statistical computing. R Foundation for Statistical Computing, Vienna, Austria. (Available from http://www.r-project.org).

Ruprecht, E. 2006. Successfully recovered grassland: a promising example from Romanian old-fields. Restoration Ecology 14:473-480.

Ryser J.-P., U. Walther, and R. Flisch. 2001. Données de base pour la fumure des grandes cultures et des herbages. Revue Suisse d'Agriculture 33: $1-80$.

Scozzafava, S., and A. De Sanctis. 2006. Exploring the effects of land abandonment on habitat structures and on habitat suitability for three passerine species in a highland area of Central Italy. Landscape and Urban Planning 75:23-33.

Smith, H., L. G. Firbank, and D. W. Macdonald. 1999. Uncropped edges of arable fields managed for biodiversity in adjacent crops. Biological Conservation 89:107-111.

Stoate, C., N. D. Boatman, R. J. Borralho, C. R. Carvalho, G. R. de Snoo, and P. Eden. 2001. Ecological impacts of arable intensification in Europe. Journal of Environmental Management 63:337-365.

Strykstra, R. J., R. M. Bekker, and G. L. Verweij. 1996. Establishment of Rhinanthus angustifolius in a successional hayfield after seed dispersal by mowing machinery. Acta Botanica Neerlandica 45:557-562.

Sutcliffe, O. L., and Q. O. N. Kay. 2000. Changes in the arable flora of central southern England since the 1960s. Biological Conservation 93: $1-8$.

Thompson, K., J. P. Bakker, and R. M. Bekker. 1997. The soil seed banks of North West Europe: methodology, density and longevity. Cambridge University Press, New York.

Tscharntke, T., A. M. Klein, A. Kruess, I. Steffan-Dewenter, and C. Thies. 2005. Landscape perspectives on agricultural intensification and biodiversity-ecosystem service management. Ecology Letters 8: $857-874$.

Türe, C., and H. Böcük. 2008. Investigation of threatened arable weeds and their conservation status in Turkey. Weed Research 48: 289-296.

Tutin, T. G., V. B. Heywood, N. A. Burges, D. H. Valentine, S. M. Walters, and D. A. Webb. 1964-1980. Flora Europea. Vols. 1-5. Cambridge University Press, Cambridge.

Waldis, R. 1987. Considérations régionales sur la flore des plantes adventices et sur l'agriculture en Valais. La Murithienne 105:3-26.

Walker, K. J., C. N. R. Critchley, A. J. Sherwood, R. Large, P. Nuttall, S. Hulmes, R. Rose, and J. O. Mountford. 2007. The conservation of arable plants on cereal field margins: an assessment of new agri-environment scheme options in England, UK. Biological Conservation 136:260-270.

Wilson, S. D., and D. Tilman. 1993. Plant competition and resource availability in response to disturbance and fertilization. Ecology 74:599-611.

Zweifel, R., L. Zimmermann, F. Zeugin, and D. M. Newbery. 2006. Intraannual radial growth and water relations of trees: implications towards a growth mechanism. Journal of Experimental Botany 57:1445-1459.

\section{Supporting Information}

Additional Supporting Information may be found in the online version of this article:

Appendix S1. List of the species observed during the experiment.

Please note: Wiley-Blackwell is not responsible for the content or functionality of any supporting materials supplied by the authors. Any queries (other than missing material) should be directed to the corresponding author for the article. 